\title{
Influence of radiopaque fillers on physicochemical properties of a model epoxy resin-based root canal sealer
}

\author{
Fabrício Mezzomo COLLARES ${ }^{1}$, Mariana KLEIN¹, Paula Dapper SANTOS ${ }^{1}$, Fernando Freitas PORTELLA¹, Fabrício \\ OGLIARI ${ }^{2}$, Vicente Castelo Branco LEITUNE'1, Susana Maria Werner SAMUEL ${ }^{1}$
}

\author{
1- LAMAD - Dental Materials Laboratory, Department of Conservative Dentistry, School of Dentistry, Universidade Federal do Rio Grande do Sul, Porto Alegre, \\ RS, Brazil. \\ 2- School of Materials Engineering, Universidade Federal de Pelotas, Pelotas, RS, Brazil.
}

Corresponding address: Fabrício Mezzomo Collares - Laboratório de Materiais Dentários, Faculdade de Odontologia, Universidade Federal do Rio Grande do Sul - Rua Ramiro Barcelos, 2492 - Porto Alegre - RS - Brasil - 90035-003 - Phone: 555133085198 - e-mail: fabricio.collares@ufrgs.br

Submitted: May 16, 2013 - Modification: August 3, 2013 - Accepted: August 23, 2013

\section{ABSTRACT}

\begin{abstract}
$\mathrm{O}$ bjective: To verify the influence of radiopaque fillers on an epoxy resin-based sealer. Material and Methods: Experimental sealers were formulated by adding $20 \%, 40 \%$, $60 \%, 80 \%, 100 \%$ and $120 \%$ of calcium tungstate, ytterbium trifluoride or barium sulphate by weight to an epoxy-resin-base. Setting time, flow, film thickness, radiopacity, sorption, solubility, $\mathrm{pH}$ and push-out bond strength were evaluated. Results: The setting time ranged from 373 to $612.66 \mathrm{~min}$, the flow varied from $13.81 \pm 0.49$ to $22.49 \pm 0.37 \mathrm{~mm}$, and the film thickness ranged from $16.67 \pm 5.77$ to $33.33 \pm 11.54 \mu \mathrm{m}$. The lowest $\mathrm{pH}$ was $5.47 \pm 0.53$, and the highest was $6.99 \pm 0.03$. Radiopacity varied from $0.38 \pm 0.04$ to $2.57 \pm 0.21 \mathrm{mmAl}$ and increased with the amount of filler. Calcium tungstate sealers had a higher sorption and solubility than other sealers. There was no significant difference in the push-out bond strength among the fillers at the $120 \%$ concentration. Conclusion: The inorganic fillers evaluated and their concentrations affect the physicochemical properties of an epoxy resin-based root canal sealer.
\end{abstract}

Key words: Tungsten. Ytterbium. Barium. Root canal filling materials.

\section{INTRODUCTION}

The success of endodontic therapy depends on a complete cleaning and three-dimensional filling of the root canal system. For ideal obturation of the canal, sealers must have certain characteristics, such as high radiopacity, flowability, adhesion to canal walls, reliable working time, biocompatibility and low solubility. Although no cement has all of these properties, some sealers, such as zinc oxideeugenol-based, calcium hydroxide-based, glassionomer and resin-based, are clinically acceptable and widely used 23,30 . Despite this, epoxy resinbased cement presents suitable physicochemical properties $^{2,7}$ and satisfactory clinical outcomes ${ }^{13}$. One of the most important properties of endodontic sealers is radiopacity. Cement radiopacity enhances diagnostic procedures and facilitates the diagnosis in Endodontics. To reach an acceptable radiopacity, inorganic fillers are added to endodontic sealers. Furthermore, these fillers improve the physical, chemical and mechanical properties of the sealer, such as viscosity and film thickness.

The radiopacity of dental materials depends on the composition of the materials (e.g., radiopaque agents) and the filler concentration. X-rays are either absorbed and/or scattered by material to produce radiographic images. Adequate radiopacity in images is necessary to avoid overtreatment and false-positive results and to obtain the proper clinical diagnosis. The chemical structures of agents that produce radiopacity in dental materials should be considered to obtain an acceptable material because the atomic number, density and size of fillers influence the radiopacity ${ }^{3}$. Elements with a high atomic number can absorb or reflect more $\mathrm{X}$-rays leading to increased radiopacity ${ }^{1}$. Besides the effects on cement radiolucency, the inorganic fillers 
could affect the polymerization shrinkage ${ }^{11}$, degree of conversion ${ }^{4}$, polymerization rate ${ }^{11}$ rheological properties ${ }^{4}$ and water absorption ${ }^{14}$ when added to resins.

Calcium tungstate $\left(\mathrm{CaWO}_{4}\right)$ and barium sulphate $\left(\mathrm{BaSO}_{4}\right)$ are already used as fillers in commercial sealers with epoxy-resin and gutta-percha cones ${ }^{12,27}$, providing high level of radiopacity ${ }^{27}$. Ytterbium trifluoride $\left(\mathrm{YbF}_{3}\right)$ contains ytterbium, which is in the lanthanide series with a high atomic number leading to a high opacity to X-rays. In addition, this filler is very translucent, which is a good optical characteristic for dental materials. Ytterbium trifluoride has already been incorporated in methacrylate-based cements ${ }^{5}$ and has shown favourable results for an endodontic sealer. However, additions of these radiopaquing fillers on epoxy resin-based root canal sealers properties were barely studied.

The purpose of this study was to evaluate the influence of the addition of different inorganic fillers on the physicochemical properties of an epoxy-resin based root canal sealer.

\section{MATERIAL AND METHODS}

Endodontic cements were prepared using an epoxy resin and inorganic fillers. The resin is composed of a bisphenol-A (Araldite ${ }^{\circledR}$ LY 1564, Huntsman Advanced Materials Química Brasil Ltda, Taboão da Serra, SP, Brazil) and a cycloaliphatic amine (Aradur 2963, Huntsman Advanced Materials Química Brasil Ltda, Taboão da Serra, SP, Brazil), base and catalyst, respectively. Base and catalyst were added at $2: 1$ ratio by weight. Calcium tungstate $\left(\mathrm{CaWO}_{4}\right)$ (American Elements, Los Angeles, $\mathrm{CA}, \mathrm{USA})$, ytterbium trifluoride $\left(\mathrm{YbF}_{3}\right)$ (American Elements, Los Angeles, CA, USA) and barium sulphate $\left(\mathrm{BaSO}_{4}\right.$ ) (Labsynth Produtos para Laboratório Ltda, Diadema, SP, Brazil) at 20\%, $40 \%, 60 \%, 80 \%, 100 \%$ and $120 \%$, in weight, were added to the amount of epoxy resin base. Colloidal silica nanoparticles (7 nm) (Aerosil 380, Evonik Industries AG, Hanau, Hesse, Germany) were added at $0.5 \%$ by weight to adjust the viscosity of cements. Base, catalyst and inorganic fillers were manually mixed for $90 \mathrm{~s}$ on a glass plate until obtaining a homogeneous paste, checked visually. A control group without radiopaquing agent filler was included. The sealers were subjected to laboratory tests to characterize selected physicochemical properties, as following.

\section{Particle size}

The particle size distribution of each filler was assessed using a laser diffraction particle size analyser (CILAS 1180 Particle-Size-Analyzer, Compagnie Industrielle des Lasers, Orleans, Loiret,
France).

\section{Setting time}

The setting time of the experimental sealers was analysed according to ISO 6876:200115. The experimental sealer was placed in a silicone matrix that had an internal diameter of $10 \mathrm{~mm}$ and a height of $1 \mathrm{~mm}$. An indenter with a mass of $100 \pm 0.5 \mathrm{~g}$ and a flat end with a diameter of $2.0 \pm 0.1 \mathrm{~mm}$ was placed vertically on the horizontal surface of the sealer for $2 \mathrm{~s}$. The surface was then visually evaluated for indentations. Indentations were repeated every 30 min until no indentation was observed, and at this moment the setting time was recorded. The mean value of three measurements for each group was recorded for the setting time of the material.

\section{Flow}

The flow test was conducted according to ISO $6876: 2001^{15}$. A total of $0.5 \mathrm{ml}$ of each experimental sealer was placed on a glass plate $(40 \times 40 \times 5 \mathrm{~mm})$ using a graduated $1.5 \mathrm{ml}$ syringe. Another plate with a mass of $20 \pm 2 \mathrm{~g}$ and a load of $100 \mathrm{~g}$ was applied to the top of the material for $180 \pm 5 \mathrm{~s}$ after mixing. Ten minutes after mixing, the load was removed, and the major and minor diameters of the compressed material were measured using a digital caliper. The results were recorded if both measurements were consistent to within $1 \mathrm{~mm}$. If the major and minor diameter discs were not uniformly circular or did not agree within a range of $1 \mathrm{~mm}$, the test was repeated. For each experimental group, the test was conducted three times and the mean value was recorded for the flow.

\section{Film thickness}

The film thickness was evaluated according to ISO 6876:2001 15 . Two glass plates that were $5 \mathrm{~mm}$ and $10 \mathrm{~mm}$ thick were placed together and their combined thickness was measured. A total of 0.5 $\mathrm{mL}$ of experimental sealer was placed at the centre of one of the plates, and a second plate was placed on top of the material. A $150 \mathrm{~N}$ load was applied vertically on the top of the glass plate $180 \pm 5 \mathrm{~s}$ after mixing. Ten minutes after the start of mixing, the thickness of the two glass plates and the sealer film was measured using a digital caliper. The difference in the thickness of the two glass plates, with and without sealer, was the film thickness of the experimental sealer. The mean value of three measurements for each sealer was recorded for the film thickness of the material.

\section{Radiopacity}

The radiopacity of the experimental sealers was tested according to ISO 6876:200115. Five specimens that were $10.0 \pm 0.1 \mathrm{~mm}$ in diameter and 
$1.0 \pm 0.01 \mathrm{~mm}$ thick were produced. Radiographic images were obtained using a phosphor plate digital system (VistaScan, Dürr Dental GmbH \& Co. KG, Bietigheim-Bissingen, Baden-Württemberg, Germany) at $70 \mathrm{kV}$ and $8 \mathrm{~mA}$ with a $0.2 \mathrm{~s}$ exposure time and a $400 \mathrm{~mm}$ focus-film distance. One specimen with the same percent filler from each group was positioned with a specimen from the control group for each film; there were a total of four specimens per film. In all images, an aluminium step-wedge was simultaneously exposed with the specimens. The aluminium step-wedge thickness ranged from 0.5 to $9.0 \mathrm{~mm}$ in increments of 0.5 $\mathrm{mm}$. The aluminium alloy used was Al 99.12, Fe $0.47, \mathrm{Mg} 0.41$ and $<0.1$ of $\mathrm{Cu}$ (\% by weight) according to ISO 6876. The images were saved in TIFF format and analysed using Photoshop (Adobe Systems Incorporated, San Jose, CA, USA). The means and standard deviations of the grey levels (pixel density) of the aluminium step-wedge and the specimens were obtained in a standardised area of $1.5 \mathrm{~mm}^{2}$.

\section{Sorption and solubility}

Water sorption and solubility tests were performed according to ISO 4049:200916, except for the specimen dimensions. The specimens had a diameter of $10 \pm 0.1 \mathrm{~mm}$ and a thickness of $1.0 \pm 0.1 \mathrm{~mm}$. The specimens were placed in desiccators containing silica gel at $37^{\circ} \mathrm{C}$. Each specimen was weighed repeatedly at $24 \mathrm{~h}$ intervals on an analytical balance (AUW220D, Shimadzu Philippines Manufacturing Inc, Cavite, Calabarzon, Philippines) until a constant mass $\left(\mathrm{m}_{1}\right)$ was obtained (i.e., until the specimen's decrease in mass was no more than $0.1 \mathrm{mg}$ in a $24 \mathrm{~h}$ period). The diameter and thickness were measured with a digital caliper to calculate the volume $(V)$ in $\mathrm{mm}^{3}$. Then, the specimens were placed in a light-free container with distilled water at $37^{\circ} \mathrm{C}$ for 7 days. The specimens were removed from the liquid, and each specimen was weighed after being dried slightly. The weight was recorded $\left(m_{2}\right)$. The procedures to obtain $m_{1}$ were repeated to obtain $\mathrm{m}_{3}$. Water sorption and solubility in micrograms per cubic millimetre were calculated according to a previous study ${ }^{6}$.

\section{$\mathrm{pH}$}

The $\mathrm{pH}$ of the sorption and solubility water was evaluated using a digital pHmeter $(\mathrm{pH} 21$, Hanna Instruments, São Paulo, SP, Brazil). Five measurements were performed per group.

\section{Push-out bond strength}

Thirty bovine incisors were sectioned transversely $15 \mathrm{~mm}$ from the apex, the pulp tissue was removed and the chemo-mechanical preparation was performed. Teeth were divided into 3 groups, and the canals were obturated by lateral condensation technique with gutta-percha points and the $120 \%$ concentration of calcium tungstate, ytterbium trifluoride and barium sulphate experimental cements. The roots were stored at $100 \%$ humidity and $37^{\circ} \mathrm{C}$ for 7 days. Subsequently, the roots were sectioned transversely into 7 slices that were approximately $0.7 \mathrm{~mm}$ thick using a low speed disc (Isomet, Buehler Ltd, Lake Bluff, IL, USA) with constant water cooling. The internal diameter of canal of each slice was measured with a digital caliper (Digimess, 100.174BL, Digimess Instrumentos de Precisão Ltda, São Paulo, SP, Brazil) and the contact area between the filling and dentin of each slice was calculated. Each slice was placed with the apical side up on a mechanical testing machine (DL-2000, EMIC Equipamentos e Sistemas de Ensaio Ltda, São José dos Pinhais, PR, Brazil). A force was placed on the shutter towards the apical-neck using a $500 \mathrm{~N}$ load cell and a cross-head speed of $1 \mathrm{~mm} / \mathrm{min}$ with a $1 \mathrm{~mm}$ diameter cylindrical device. The bond strength ( $\mathrm{MPa}$ ) was obtained by dividing the required force $(\mathrm{N})$ to displace the filling material by the adhesive area $\left(\mathrm{mm}^{2}\right)$.

\section{Statistical analysis}

Data normality was checked by the KolmogorovSmirnov test. Differences among filler compositions and control group were detected using ANOVA and the Tukey post-hoc test. Linear regression was performed to determine the influence of filler composition on radiopacity. A significance level of $5 \%$ was used for analysis.

\section{RESULTS}

The mean particle sizes of calcium tungstate, ytterbium trifluoride and barium sulphate were $17.79 \mu \mathrm{m}, 14.37 \mu \mathrm{m}$ and $4.86 \mu \mathrm{m}$, respectively. Table 1 shows the setting time, flow, film thickness, sorption, solubility and water $\mathrm{pH}$ of experimental sealers. The setting time of experimental sealers ranged from 373 to $612.66 \pm 4.71 \mathrm{~min}$, the flow of experimental sealers ranged from $13.81 \pm 0.49$ to $22.49 \pm 0.37 \mathrm{~mm}$ and the film thickness ranged from $16.67 \pm 5.77$ to $33.33 \pm 11.54 \mu \mathrm{m}$. The $\mathrm{pH}$ of experimental sealers ranged from $5.47 \pm 0.53$ to $6.99 \pm 0.03$.

Radiopacity ranged from $0.38 \pm 0.04$ to $2.57 \pm 0.21 \mathrm{mmAl}$ (Table 2) and increased with the amount of filler $\left(\mathrm{CaWO}_{4} \mathrm{r}^{2}=0.996, \mathrm{YbF}_{3} \mathrm{r}^{2}=0.983\right.$, $\left.\mathrm{BaSO}_{4} \mathrm{r}^{2}=0.994 ; \mathrm{p}<0.05\right)$. Table 3 show the water sorption and water solubility of experimental groups compared to the controls. The push-out bond strengths for groups containing $120 \%$ of filler were $3.26 \pm 1.34 \mathrm{MPa}\left(\mathrm{CaWO}_{4}\right), 4.48 \pm 1.66 \mathrm{MPa}$ $\left(\mathrm{YbF}_{3}\right)$ and $4.73 \pm 1.53 \mathrm{MPa}\left(\mathrm{BaSO}_{4}\right)$ and there was 
Table 1- Means \pm standard deviation for the setting time, flow, film thickness and $\mathrm{pH}$ of experimental sealers

\begin{tabular}{|c|c|c|c|c|c|c|}
\hline & \multicolumn{6}{|c|}{ Filler concentration } \\
\hline & $20 \%$ & $40 \%$ & $60 \%$ & $80 \%$ & $100 \%$ & $120 \%$ \\
\hline \multicolumn{7}{|c|}{ setting time (min) } \\
\hline $\mathrm{CaWO}_{4}$ & $451.66 \pm 4.71$ & $430 \pm 8.17$ & $453 \pm 8.17$ & $509 \pm 0$ & $501 \pm 0$ & $448.66 \pm 11.79$ \\
\hline $\mathrm{YbF}_{3}$ & $612.66 \pm 4.71$ & $570 \pm 7.07$ & $546.66 \pm 4.71$ & $373 \pm 0$ & $388 \pm 0$ & $378 \pm 0$ \\
\hline $\mathrm{BaSO}_{4}$ & $468.66 \pm 6.13$ & $478.66 \pm 6.13$ & $486.66 \pm 6.24$ & $451.66 \pm 10.21$ & $384.66 \pm 2.36$ & $398.33 \pm 10.27$ \\
\hline \multicolumn{7}{|l|}{ flow (mm) } \\
\hline $\mathrm{CaWO}_{4}$ & $20.26 \pm 0.51$ & $18.92 \pm 2.16$ & $19.28 \pm 0.57$ & $18.10 \pm 1.28$ & $15.02 \pm 1.81$ & $15.85 \pm 0.25$ \\
\hline $\mathrm{YbF}_{3}$ & $20.93 \pm 0.17$ & $18.41 \pm 0.35$ & $18.50 \pm 0.92$ & $15.50 \pm 0.38$ & $13.81 \pm 0.49$ & $14.59 \pm 0.70$ \\
\hline $\mathrm{BaSO}_{4}$ & $22.49 \pm 0.37$ & $21.36 \pm 0.37$ & $19.43 \pm 0.21$ & $17.96 \pm 0.21$ & $18.08 \pm 1.21$ & $17.69 \pm 0.17$ \\
\hline \multicolumn{7}{|c|}{ film thickness $(\mu \mathrm{m})$} \\
\hline $\mathrm{CaWO}_{4}$ & $23.33 \pm 5.77$ & $30 \pm 0$ & $26.67 \pm 5.77$ & $26.67 \pm 5.77$ & $33.33 \pm 5.77$ & $23.33 \pm 11.55$ \\
\hline $\mathrm{YbF}_{3}$ & $16.67 \pm 5.77$ & $26.67 \pm 5.77$ & $33.33 \pm 5.77$ & $30 \pm 0$ & $30 \pm 0$ & $33.33 \pm 5.77$ \\
\hline $\mathrm{BaSO}_{4}$ & $33.33 \pm 11.54$ & $23.33 \pm 5.77$ & $46.67 \pm 5.77$ & $20 \pm 0$ & $16.67 \pm 5.77$ & $20 \pm 0$ \\
\hline \multicolumn{7}{|l|}{$\mathrm{pH}$} \\
\hline $\mathrm{CaWO}_{4}$ & $6.31 \pm 0.13$ & $6.69 \pm 0.08$ & $6.66 \pm 0.08$ & $6.82 \pm 0.08$ & $6.84 \pm 0.05$ & $6.99 \pm 0.03$ \\
\hline $\mathrm{YbF}_{3}$ & $6.74 \pm 0.08$ & $5.47 \pm 0.53$ & $5.69 \pm 0.30$ & $6.11 \pm 0.22$ & $6.25 \pm 0.21$ & $6.31 \pm 0.21$ \\
\hline $\mathrm{BaSO}_{4}$ & $6.28 \pm 0.09$ & $6.27 \pm 0.10$ & $6.37 \pm 0.12$ & $6.40 \pm 0.10$ & $6.45 \pm 0.16$ & $6.51 \pm 0.19$ \\
\hline
\end{tabular}

Table 2- Means \pm standard deviation for the radiopacity $(\mathrm{mmAl})$ of experimental sealers*

\begin{tabular}{lcccccc}
\hline & \multicolumn{5}{c}{ Filler concentration } \\
& $\mathbf{2 0} \%$ & $\mathbf{4 0} \%$ & $\mathbf{6 0 \%}$ & $\mathbf{8 0} \%$ & $\mathbf{1 0 0} \%$ & $\mathbf{1 2 0} \%$ \\
\hline $\mathrm{CaWO}_{4}$ & $0.44 \pm 0.04$ & $0.91 \pm 0.06$ & $1.24 \pm 0.15$ & $1.56 \pm 0.14$ & $1.98 \pm 0.10$ & $2.43 \pm 0.05$ \\
$\mathrm{YbF}_{3}$ & $0.38 \pm 0.04$ & $0.76 \pm 0.20$ & $1.47 \pm 0.37$ & $1.63 \pm 0.11$ & $2.07 \pm 0.05$ & $2.57 \pm 0.21$ \\
$\mathrm{BaSO}_{4}$ & $0.44 \pm 0.06$ & $0.63 \pm 0.21$ & $1.01 \pm 0.10$ & $1.29 \pm 0.09$ & $1.62 \pm 0.16$ & $2.00 \pm 0.07$ \\
\hline
\end{tabular}

*Radiopacity increases with the amount of filler $\left(\mathrm{CaWO}_{4} \mathrm{r}^{2}=0.996, \mathrm{YbF}_{3} \mathrm{r}^{2}=0.983, \mathrm{BaSO}_{4} \mathrm{r}^{2}=0.994 ; \mathrm{p}<0.05\right)$

Table 3- Means \pm standard deviation for the water sorption and solubility of experimental sealers

\begin{tabular}{ccccccc}
\hline & $\mathbf{2 0} \%$ & $\mathbf{4 0} \%$ & $\mathbf{6 0 \%}$ & $\mathbf{8 0} \%$ & $\mathbf{1 0 0 \%}$ & $120 \%$ \\
\hline Sorption $\left(\mu \mathrm{g} / \mathrm{mm}^{3}\right)$ & & & & & & \\
$\mathrm{CaWO}_{4}$ & $145.57 \pm 2.81^{*}$ & $182.08 \pm 12.15^{*}$ & $167.53 \pm 12.09^{*}$ & $236.25 \pm 22.46^{*}$ & $183.21 \pm 6.35^{*}$ & $200.72 \pm 3.67^{*}$ \\
$\mathrm{YbF}_{3}$ & $69.24 \pm 6.54$ & $79.14 \pm 5.10^{*}$ & $80.10 \pm 1.93^{*}$ & $62.36 \pm 4.18$ & $67.75 \pm 5.97$ & $70.01 \pm 7.06$ \\
$\mathrm{BaSO}_{4}$ & $60.84 \pm 7.21$ & $54.52 \pm 2.67$ & $51.73 \pm 2.41^{*}$ & $52.36 \pm 2.48^{*}$ & $51.26 \pm 5.87^{*}$ & $45.20 \pm 11.26^{*}$ \\
\hline Solubility $\left(\mu \mathrm{g} / \mathrm{mm}^{3}\right)$ & & & & & & \\
\hline $\mathrm{CaWO}_{4}$ & $105.18 \pm 10.45^{*}$ & $151.18 \pm 25.53^{*}$ & $157.14 \pm 10.96^{*}$ & $180.79 \pm 31.50^{*}$ & $200.10 \pm 11.92^{*}$ & $264.95 \pm 11.63^{*}$ \\
$\mathrm{YbF}_{3}$ & $15.42 \pm 1.83^{*}$ & $14.00 \pm 3.08^{*}$ & $9.96 \pm 0.64$ & $8.16 \pm 1.12$ & $10.71 \pm 1.61$ & $11.83 \pm 1.93$ \\
$\mathrm{BaSO}_{4}$ & $10.44 \pm 2.58$ & $10.84 \pm 2.17$ & $10.02 \pm 1.10$ & $13.16 \pm 0.68$ & $13.15 \pm 0.92$ & $8.11 \pm 8.7$ \\
\hline
\end{tabular}

*Statistical difference $(p<0.05)$ against control group. Water soprtion and solubility of control group are $64.28 \pm 3.79 \mu \mathrm{g} / \mathrm{mm}^{3}$ and $9.93 \pm 2.20 \mu \mathrm{g} / \mathrm{mm}^{3}$, respectively 


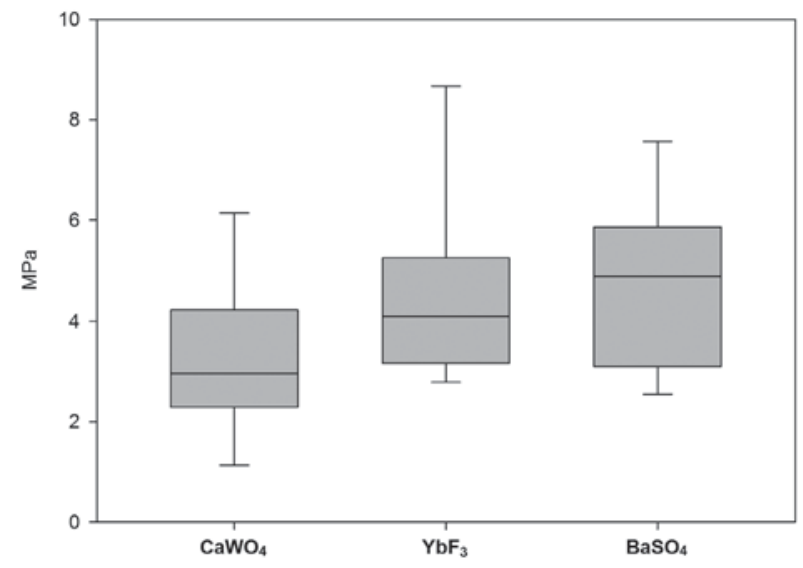

Figure 1- Push-out bond strength (MPa) of the groups with $120 \%$ filler by weight. There are no differences between groups $(p>0.05)$

no significant difference between the experimental groups as shown in Figure 1.

\section{DISCUSSION}

Improved physical properties of materials and diagnoses could lead to a higher success rate for root canal treatments. The addition of radiopaque fillers to root canal sealers could interfere with the physical and mechanical properties of the sealers ${ }^{4,20}$. In this study, the concentration of the filler influenced the setting time, flow, film thickness, radiopacity, sorption and solubility of root canal sealers.

The setting time of endodontic sealers should be long enough to allow the filling of the entire root canal system without displacement of the obturation material and the formation of gaps to avoid subsequent bacterial leakage, which could decrease the longevity of the treatment. In this study, the setting time of the sealers ranged from approximately 6 to $10 \mathrm{~h}$. There is no standard for the setting time of endodontic sealers according to ISO 6876. However, the setting time of experimental sealers was suitable to permit root canal filling within an adequate time.

The ability to penetrate accessory canals, dentinal tubules and constitute a thin layer between core materials (e.g. guta-percha points), in order to fill the smallest voids and prevent fluid percolation through the root canal system, is a concern in Endodontics, and this ability is related to flow and film thickness of sealers. All groups present flow nearest to $20 \mathrm{~mm}$ and film thickness under $50 \mu \mathrm{m}$, which are within the parameters outlined by ISO 6876. The flow and film thickness are directly influenced by the composition of the sealer, temperature and relative humidity. The literature presents different flow and film thickness values for commercial materials ${ }^{26,28}$. The flow of the other two commercial resin-based sealers also had flow and film thickness values lower than those outlined in ISO 6876. In addition, the flow of the sealer cannot be too high due to a possible periapical extrusion, which could compromise apical healing and lead to decreased tooth longevity ${ }^{24}$. The film thickness of experimental sealers was similar to widely used commercial sealers, which have film thicknesses of approximately $50 \mu \mathrm{m}^{10}$.

The addition of radiopaque agents to root canal filling materials should ideally enable their visualisation and assessment on a radiograph without altering their chemical properties. The high atomic numbers of ytterbium $(z=70)$, barium $(z=56)$ and tungsten $(z=74)$ could explain the increase in radiopacity as the amount of filler increases. Elements with high atomic numbers can absorb more X-rays, leading to a radiopaque image $^{1,21}$. Experimental groups containing $120 \%$ radiopaque agent by weight were more radiopaque than $2 \mathrm{~mm}$ of aluminium, which allowed the sealer to be feasibly identified on a radiograph.

In this study, the sorption and solubility values of experimental sealers were influenced by the addition of radiopaque filler. Calcium tungstate groups had higher sorption and solubility values than other groups. These results may be explained by the calcium tungstate particle size, which has a higher mean diameter than ytterbium trifluoride and barium sulphate. The increased particle size causes the $\mathrm{CaWO}_{4}$ particles to be more soluble in water even though the solubility coefficient of calcium tungstate $(2.39 \mathrm{mg} / 100 \mathrm{ml})$ is lower than those of ytterbium trifluoride $(5.77 \mathrm{mg} / 100 \mathrm{ml})$ and barium sulphate $(0.24 \mathrm{mg} / 100 \mathrm{ml})$. Water sorption and solubility have a significant influence on the mechanical properties and degradation of endodontic sealers. Sealers degrade over time as a result of the sorption/solubility process, which could promote resin/filler lixiviation ${ }^{9}$ and consequently cause porosities on obturation mass. The ISO 6876 details the normalisation of root canal sealing materials but does not consider resin-based material. For this reason, in this study we adopted ISO 4049, a standard for polymer-based filling and restorative and luting materials, even though it is not specific for root canal filling materials. According to ISO 4049, the water sorption of resin-based material cannot be higher than $40 \mu \mathrm{g} / \mathrm{mm}^{3}$ and the water solubility must be up to $7.5 \mu \mathrm{g} / \mathrm{mm}^{3}$. The values obtained from sealers containing different fillers, especially the calcium tungstate sealers, do not meet these standards. However, the ytterbium trifluoride and barium sulphate sealers had sorption and solubility values that met ISO 4049 standards. The matrix properties of root canal sealers are important features that predict the solubility of cements. The literature presents a wide range of solubility data for different compositions of sealers 
showing that the epoxy matrix is more resistant to water diffusion than other matrices, such as ionomeric and methacrylate, and water-based cements ${ }^{7}$. Furthermore, the process of periapical repair requires favourable conditions, such as the absence of microorganisms and an adequate $\mathrm{pH}^{8}$. Root canal sealers that are in close contact with periapical tissues could interfere with the periapical repair. Lixiviation of sealers as result of solubility could also cause changes in the $\mathrm{pH}$ of the periapical environment. An alkaline or neutral $\mathrm{pH}$ provides the best conditions for the healing process. All sealers tested in this study had a $\mathrm{pH}$ that was close to neutral.

The fluid leakage at root canal sealers interface is a concern to root canal filling longevity. To analyze the dentin-sealer interface, push-out bond strength test showed a good correlation with microleakage elsewhere ${ }^{22,29}$. In this study, the pushout bond strengths were tested for the groups with high radiopacity ( $120 \%$ filler by weight), and no significant differences were observed. The mean values of bond strength agreed with studies that evaluated commercial epoxy-based root canal sealers ${ }^{17}$. Theoretically, resin-based root canal sealers could have micromechanical retention with dentin substrate leading to a more stable interface that prevents degradation over time.

Despite the fact of being an in vitro study, the present study clearly identified differences in properties as function of filler type and concentration. The Dental Materials field has the obligation of research development of new materials and provide the experimental explanation of mechanisms involved in phenomena $4,5,18-20,25$. Furthermore, identifying these differences between fillers provides data to clinicians to take more evidencebased decisions regarding the acquisition of root canal sealers.

\section{CONCLUSION}

The inorganic fillers evaluated and their concentrations affect the physicochemical properties of an epoxy resin-based root canal sealer. Ytterbium trifluoride and barium sulphate at $120 \%$ of concentration showed adequate properties to be used as fillers at epoxy resin-based root canal sealers.

\section{REFERENCES}

1- Aoyagi Y, Takahashi H, Iwasaki N, Honda E, Kurabayashi T. Radiopacity of experimental composite resins containing radiopaque materials. Dent Mater J. 2005;24:315-20.

2- Bernardes RA, Amorim Campelo A, Junior DS, Pereira LO, Duarte MA, Moraes IG, et al. Evaluation of the flow rate of 3 endodontic sealers: Sealer 26, AH Plus, and MTA Obtura. Oral Surg Oral Med Oral Pathol Oral Radiol Endod. 2010;109:e47-9.

3- Bowen RL, Cleek GW. X-ray-opaque reinforcing fillers for composite materials. J Dent Res. 1969;48:79-82.

4- Collares FM, Leitune VC, Rostirolla FV, Trommer RM, Bergmann $\mathrm{CP}$, Samuel SMW. Nanostructured hydroxyapatite as filler for methacrylate-based root canal sealers. Int Endod J. 2012;45:63-7. 5- Collares FM, Ogliari FA, Lima GS, Fontanella VR, Piva E, Samuel SM. Ytterbium trifluoride as a radiopaque agent for dental cements. Int Endod J. 2010;43:792-7.

6- Collares FM, Ogliari FA, Zanchi CH, Petzhold CL, Piva E, Samuel $\mathrm{SM}$. Influence of 2-hydroxyethyl methacrylate concentration on polymer network of adhesive resin. J Adhes Dent. 2011;13:125-9. 7- Donnelly A, Sword J, Nishitani Y, Yoshiyama M, Agee K, Tay FR, et al. Water sorption and solubility of methacrylate resin-based root canal sealers. J Endod. 2007;33:990-4.

8- Estrela C, Sydney GB, Bammann LL, Felippe Júnior O. Mechanism of action of calcium and hydroxyl ions of calcium hydroxide on tissue and bacteria. Braz Dent J. 1995;6:85-90.

9- Ferracane JL. Hygroscopic and hydrolytic effects in dental polymer networks. Dent Mater. 2006;22:211-22.

10- Gambarini G, Testarelli L, Pongione G, Gerosa R, Gagliani M. Radiographic and rheological properties of a new endodontic sealer. Aust Endod J. 2006;32:31-4.

11- Gonçalves F, Azevedo CL, Ferracane JL, Braga RR. BisGMA/ TEGDMA ratio and filler content effects on shrinkage stress. Dent Mater. 2011;27:520-6.

12- Gurgel-Filho ED, Andrade Feitosa JP, Teixeira FB, Monteiro de Paula RC, Araújo Silva JB, Souza-Filho FJ. Chemical and X-ray analyses of five brands of dental gutta-percha cone. Int Endod J. 2003;36:302-7.

13- Hale R, Gatti R, Glickman GN, Opperman LA. Comparative analysis of carrier-based obturation and lateral compaction: a retrospective clinical outcomes study. Int J Dent. 2012;2012:954675.

14- Hsu SH, Chen RS, Chang YL, Chen MH, Cheng KC, Su WF. Biphenyl liquid crystalline epoxy resin as a low-shrinkage resin-based dental restorative nanocomposite. Acta Biomater. 2012;8:4151-61.

15- International Organization for Standardization. ISO 6876: Dental root canal sealing materials. Geneva: ISO; 2001.

16- International Organization for Standardization. ISO 4049: Dentistry - Polymer-based restorative materials. Geneva: ISO; 2009.

17- Lawson MS, Loushine B, Mai S, Weller RN, Pashley DH, Tay $\mathrm{FR}$, et al. Resistance of a 4-META-containing, methacrylate-based sealer to dislocation in root canals. J Endod. 2008;34:833-7.

18- Leitune VC, Collares FM, Takimi A, Lima GB, Petzhold CL, Bergmann $C P$, et al. Niobium pentoxide as a novel filler for dental adhesive resin. J Dent. 2013;41:106-13.

19- Leitune VC, Collares FM, Trommer RM, Andrioli DG, Bergmann $\mathrm{CP}$, Samuel SM. The addition of nanostructured hydroxyapatite to an experimental adhesive resin. J Dent. 2013;41:321-7.

20- Leitune VC, Takimi A, Collares FM, Santos PD, Provenzi $C$, Bergmann $\mathrm{CP}$, et al. Niobium pentoxide as a new filler for methacrylate-based root canal sealers. Int Endod J. 2013;46:20510.

21- Moszner N, Salz U. New developments of polymeric dental composites. Prog Polym Sci. 2001;26:535-76.

22- Neelakantan P, Subbarao C, Subbarao CV, De-Deus G, Zehnder $M$. The impact of root dentine conditioning on sealing ability and push-out bond strength of an epoxy resin root canal sealer. Int Endod J. 2011;44:491-8. 
23- Ng YL, Mann V, Gulabivala K. Outcome of secondary root canal treatment: a systematic review of the literature. Int Endod J. 2008;41:1026-46.

24- Ng YL, Mann V, Gulabivala K. A prospective study of the factors affecting outcomes of non-surgical root canal treatment: part 2: tooth survival. Int Endod J. 2011;44:610-25.

25- Portella FF, Santos PD, Lima GB, Leitune VC, Petzhold CL, Collares FM, et al. Synthesis and characterization of a glycero salicylate resin for bioactive root canal sealers. Int Endod J. 2013. Epub ahead of print.

26- Resende LM, Rached-Junior FJ, Versiani MA, Souza-Gabriel $A E$, Miranda CE, Silva-Sousa $Y T$, et al. A comparative study of physicochemical properties of AH Plus, Epiphany, and Epiphany SE root canal sealers. Int Endod J. 2009;42:785-93.
27- Tanomaru-Filho M, Tanomaru JM, Leonardo MR, Silva LA. Periapical repair after root canal filling with different root canal sealers. Braz Dent J. 2009;20:389-95.

28- Versiani MA, Carvalho-Junior JR, Padilha MI, Lacey S, Pascon EA, Sousa-Neto MD. A comparative study of physicochemical properties of $\mathrm{AH}$ Plus and Epiphany root canal sealants. Int Endod J. 2006;39:464-71.

29- Zicari F, Couthino E, De Munck J, Poitevin A, Scotti R, Naert I, et al. Bonding effectiveness and sealing ability of fiber-post bonding. Dent Mater. 2008;24:967-77.

30- Zmener O, Pameijer $\mathrm{CH}$. Clinical and radiographic evaluation of a resin-based root canal sealer: an eight-year update. J Endod. 2010;36:1311-4. 